\title{
The Influence Of User-Generated Content To Consumer-Based Brand Equity Through Involvement In Indonesia's Top Brand Lipstic Consumer
}

Sunu Puguh Hayu Triono ${ }^{1}$, Ratih Huriyati ${ }^{2}$ and Mokh Adib Sultan ${ }^{3}$

1, 2, ${ }^{3}$ Doktor Ilmu Manajemen, Sekolah Pascasarjana, Universitas Pendidikan Indonesia, Bandung, Indonesia

\begin{abstract}
Since 2000's content marketing began to develop and become a buzzword lately. Nowadays, content marketing is a standard practice of business and one who do not use that will be left behind. The current democratization of information is expressed mainly through User-Generated Content (UGC), so that the media model becomes more user-centric. This study attempts to discuss the effect of UGC on consumer-based brand equity (CBBE) through involvement. UGC in this study is represented through variables that motivate it, namely co-creation, empowerment, community, and self-concept. The population in this study is Top Brand lipstick consumers who have watched the UGC of those brands. Data was collected using questionnaire that distributed online and 121 data were obtained. After analyzed using SEM PLS, the results are: 1) co-creation has positive effect on involvement; 2) self-concept has positive effect on involvement; 3) involvement has a positive effect on CBBE; 4) $U G C$ has a substantial influence on involvement; 5) UGC and involvement have a moderate influence on CBBE.
\end{abstract}

Keywords - brand equity; consumer-based brand equity; content marketing; involvement; user-generated content

\begin{abstract}
Abstrak
Content marketing sejak tahun 2000 mulai berkembang dan menjadi buzzword akhir-akhir ini. Content marketing menjadi praktek standar perusahaan-perusahaan saat ini, dan perusahaan yang tidak menggunakannya akan tertinggal. Demokratisasi informasi yang terjadi saat ini utamanya diekspresikan melalui User-Generated Content (UGC), sehingga model media menjadi lebih user-centric. Penelitian ini bertujuan untuk memahami pengaruh UGC terhadap consumer-based brand equity (CBBE) melalui involvement. UGC pada penelitian ini direpresentasikan melalui variabel yang memotivasinya yaitu co-creation, empowerment, community, dan selfconcept. Populasi pada penelitian ini yaitu konsumen lipstik Top Brand yang pernah menonton UGC brand tersebut. Data dikumpulkan melalui kuesioner yang disebarkan secara online dan diperoleh 121 data yang sesuai kriteria. Setelah dianalisis menggunakan SEM PLS, diperoleh hasil yaitu: 1) co-creation berpengaruh positif terhadap involvement; 2) self-concept berpengaruh positif terhadap involvement; 3) involvement berpengaruh positif terhadap CBBE; 4) UGC memiliki pengaruh substansial terhadap involvement; 5) UGC dan involvement memiliki pengaruh yang moderat terhadap CBBE.
\end{abstract}

Kata kunci- brand equity; consumer-based brand equity; content marketing; involvement; user-generated content

\section{INTRODUCTION}

Marketing as an effort to understand the needs and human desires, need to combine many different fields, such as economics, business, psychology, sociology, or even anthropology. Basically, a marketer is required to be able to understand humans, both individually and in groups, then utilizing various factors, both internal and external, so that the sales can occur. From the pragmatic point of view, marketing as a method or technique in doing such engineering is related directly to the ongoing context. So that marketing develops from product-driven (1.0) to consumer-oriented (2.0), then develops to be human-centric (3.0) and then the development of digital technology 
is in turn changes economic conditions and digital economies emerge. All of those changes, accumulatively, makes marketing need to adapt, so marketing 4.0 then emerge. The key themes of marketing 4.0 lay in digital economics such as sharing-economy, the now-economy, omnichannel, social customer relationship management, content marketing, etc.

Nowadays, content marketing is a standard practice of business and one who do not use that will be left behind (Ruffolo, 2017). Content marketing is an approach of marketing that use content (digital content) to creates some engagement through conversation with customer, so the content need to carefully selected, planned, deliver, and amplified, to meet the targeted customers style (Kotler et al., 2017). Content marketing is mostly driven by social media, where in the previous era consumers had little choice of information except advertisements from broadcast media. However, with the democratization of information through social media, anyone could create content. It turns out that the content which generated by consumers - user-generated content (UGC)- is preferred and trusted by the other consumers. Contents in YouTube that is most watched are UGC, so is the most subscribed channels (Kotler et al., 2017).

Articles about content marketing can be traced since 2000 and since then the discussions have increased and become hottest buzzword lately (Mayer et al., 2000; Keyes, 2006; Pulizzi \& Barrett, 2009; Halvorson, 2010; Handley \& Chapman, 2010; Gunelius, 2011; Lieb, 2011; Nelli, 2012; Christodoulides et al., 2012; Jefferson \& Tanton, 2013; Rahimia \& Hassanzadeh, 2013; Slater, 2014; Ramos, 2014; Elisa \& 2014 Gordini, 2014; Forrest, 2019). Content marketing is touted as a form of advertising in the era of the digital economy, ultimately aimed at generating curiosity about a brand (Kotler et al., 2017). With the democratization of information, starting with the Web 2.0 era, the role of internet users has increased, not only as consumers, but also producers of information. The role of users is becoming increasingly dominant with the presence of social media technology, so that online digital content is dominated by content generated by user (UGC).

Christodoulides et al. (2012) obtained a model about content marketing that involving UGC and analyze the content creators. This study analyzing the relationship of UGC, involvement of user, and consumer-based brand equity (CBBE). However, they suggested to test the model with different subject, that is from content viewer. The unit of analysis used in this study is the consumer of Top Brand Indonesia lipstick in 2019, namely Wardah, Revlon, Maybelline, Pixy, and Viva. Lipstick products were chosen because they are cosmetic products that are commonly used by women, are easily found anywhere, and quite a lot of the consumer that creates a content, especially online reviews.

\section{LITERATURE REVIEW}

In this transition era, a new marketing approach is needed. Thus, Kotler et al. (2017) introduced marketing 4.0 as a continuity from marketing 3.0. The main cause of this evolution is the change of customers characteristics and nature in the face of digital economy. Marketing 4.0 need to be more human-centered, so the brands has such intimacy with the customer by humanizing the brands, have conversation through content, upscale the sales by integrating many form of channels (omnichannel), and involving customer more.

Content marketing is an approach of marketing that use content (digital content) to creates some engagement through conversation with customer, so the content need to carefully selected, planned, deliver, and amplified, to meet the targeted customers style (Kotler et al., 2017). By using content marketing, the deeper connection or relationship with customer might be easier to achieve. The early UGC was marked by participatory inequality in which the parties could create only a few among others (Ochoa \& Duval, 2008), so that from its origin, UGC was a niche activity and was driven by the accumulation of various things (Daugherty, Eastin, \& Bright, 2008). The most frequently cited definition of UGC comes from the Organization for Economic Co-operation and Development (OECD) (2007), which defines UGC as having three main characteristics: content made publicly available via the internet; content that reflects a number of creative endeavors; and content created outside routine and professional practice.

From personal characteristics, Daugherty et al. (2011) state that there are three things that motivate people to consume UGC, namely attitudes towards UGC, media experience, and the desire to control. To this, it can be observed that the factors driving the creation of UGC that proposed by Christodoulides et al. (2012) are still relevant to various factors that motivate people to consume UGC. Therefore, in this study the same factors as Christodoulides et al. (2012) are used to test the research models, namely co-creation, empowerment, community, and self-concept. 
Vargo \& Lusch (2004) stated that co-creation is the participation of customer in creating value, at any points. Meanwhile, UGC is an online content that produced by consumer, involving collaboration with other consumer or the companies itself, and that adds value for companies (Humphreys \& Grayson, 2008). In this democratize internet era, consumer has more power in determining their information consumption. The consumer perception of control can be achieved by accessing online content that other consumer creates (UGC) so it enabling them to have more connection (Harrison, Hunter \& Waite, 2006) and able to define their own brand value (Christodoulides et al., 2009). The study of Wathieu et al. (2002) stated that there are three factors that influence consumer empowerment, those are the ability to determine choices, sense of progress in decision making process, and information of the other consumer.

Social web allows communities that is not passive, rather interactive and involve in co-creation of brand value (de Chernatony \& Christodoulides, 2004). It should be noted that UGC is primarily driven by digital-born or digital natives generation that characterized by young and digitally skilled, and behave differently from the previous generation (Burmann \& Arnhold, 2008). Consumer can share their ideas or express themselves by involving in UGC. Consumer self-concepts influence the way they see the personality of a brand. For example, favored brands are formed, partly, by personalities that are preferred by consumers. By utilizing brands, UGC allows consumers to attract attention and to tell who they are from their own perspective (Berthon et al., 2008).

Involvement influenced by three main factors, those factors are related to the characteristics of the person, the stimulus, and the situation (Zaichkowsky, 1986; Bloch \& Richins, 1983). These factors can influence the level of involvement with product, advertising, or purchasing situation (Hupfer \& Gardner, 1971; Krugman, 1965, 1967; Clarke \& Belk 1978). Customer involvement is a significant factor in influencing customer behavior and higher involvement means higher loyalty (Jones \& Sasser, 1995; Knox \& Walker, 2003).

Concept of brand equity is referred as more consumers view or based on consumer (CBBE) for some researchers (Cobb-Walgren et al., 1995; Sinha \& Pappu, 1998; Yoo \& Donthu, 2001, 2002; Yoo et al., 2000; Washburn \& Plank, 2002). CBBE according to Aaker (1991) is "A set of brand assets and liabilities linked to a brand, its name and symbol that add to or subtract from the value provided by a product or service to a firm and / or to that firm's customers". Schivinski \& Dabrowski (2014) measures CBBE refers to four of Aaker's five core brand equity dimensions, namely: brand awareness, brand association, perceived quality, and brand loyalty.

From those literature study, we propose five hypotheses and then arranged to the research model as follows:

$\mathrm{H}_{1}$ : Co-creation has positive effect on consumer involvement with the brand through UGC.

$\mathrm{H}_{2}$ : Consumer empowerment has positive effect on consumer involvement with the brand through UGC.

$\mathrm{H}_{3}$ : Community has positive effect on consumer involvement with the brand through UGC.

$\mathrm{H}_{4}$ : Self-concept has positive effect on consumer involvement with the brand through UGC.

$\mathrm{H}_{5}$ : Consumer involvement has positive effect on consumer-based brand equity. 


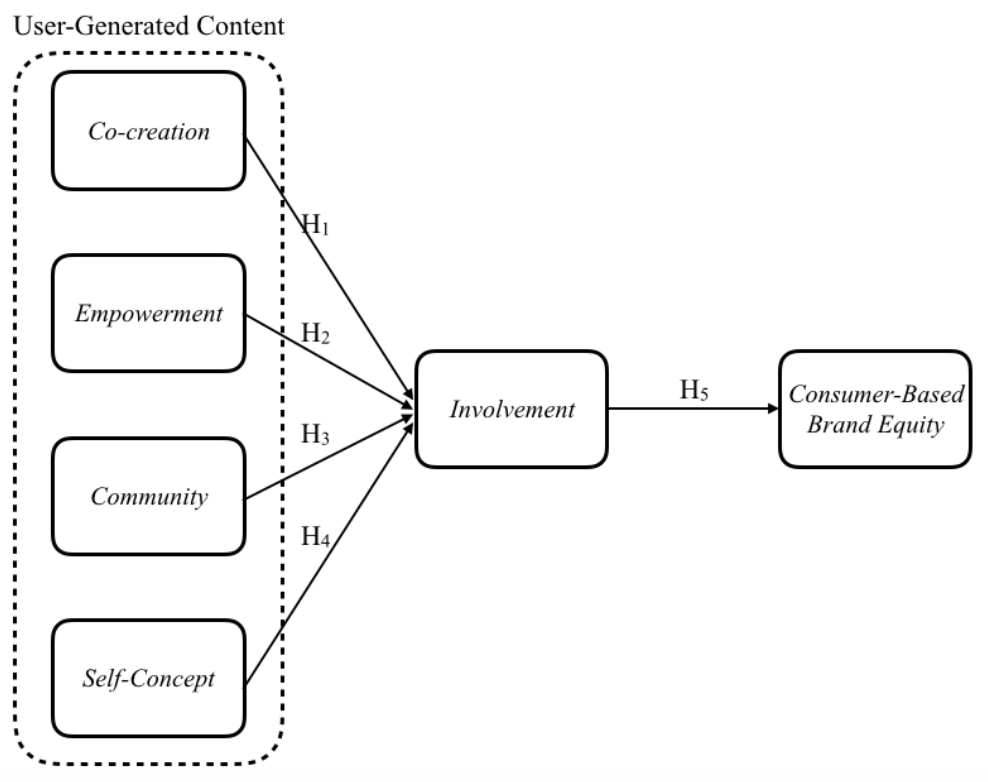

Fig. 1 Research Model

\section{RESEARCH METHODOLOGY}

The analysis technique used in this study is Partial Least Square (PLS) using SmartPLS 3.0 software. The population is consumers of Top Brand Indonesia's lipstick in 2019 (Wardah, Maybelline, Revlon, Pixy, Viva) who have watched UGC of those brands. The size of population is unknown because there is no data of exact number of Top Brand lipstick consumers and those who have watched the UGC. Even so, because this study uses PLS, then the minimum number of respondents can be concluded as five times of path (50 respondents). This study uses nonprobability sampling and using purposive or judgmental sampling method. Data collection was carried out using a questionnaire created in digital format using GoogleForm and distributed online. Out of 143 responses, 121 responses were chosen that fit the criteria.

The questionnaire was arranged in two parts. The first part contains respondent's characteristics and a question about whether or not they watch UGC Top Brand lipstick. If the respondent ever watched the UGC, then they proceed to the second part which contains questions about the variables. But if they has never watched the UGC, then the filling process is immediately stated as complete.

Co-creation is measured using four question items. Empowerment was measured using three questions. Community is measured using three questions. Self-concept is measured using two questions. Question items for measuring those four variables were adopted from Christodoulides et al. (2012) based on interval scales ranging from 1 to 7 to state the level of agreement. Whereas to measure involvement, it was adopted from Zaichkowsky (1994) using seven semantic differential scale items that has range from 1 to 7 . To measure CBBE, 13 question items were adopted from Schivinski \& Dabrowski (2014) with interval scale ranging from 1 to 7.

\section{RESULT OF STUDY AND DISCUSION}

There are five questions related to the respondent's characteristics, namely gender, age, occupation, income, and the UGC brand that they ever watched.

Table 1. Sample Demography by Gender

\begin{tabular}{ll}
\hline Gender & Number \\
\hline Male & 12 \\
Female & 109 \\
\hline
\end{tabular}


Based on gender, 109 respondents were female and 12 male respondents. This is not surprising considering the product is lipstick, a product whose designed for women. Even so, it turns out there are male respondents who have watched the UGC of lipstick.

Table 2. Sample Demography by Age

\begin{tabular}{ll}
\hline Age (years old) & Number \\
\hline $15-25$ & 52 \\
$25-35$ & 35 \\
$35-45$ & 28 \\
$>45$ & 6 \\
\hline
\end{tabular}

Based on age, it can be seen from Table 2 that the composition of respondents is dominated by the range of 15 - 25 years old (generation $\mathrm{Z}$ ) which is 52 respondents or $42.98 \%$ of the total respondents. The second most is the range of $25-35$ years (generation Y) totaling 35 respondents or $28.93 \%$ of the total respondents. Respondents from generation $\mathrm{Y}$ and $\mathrm{Z}$, or commonly referred as millennials, dominate the total respondents. This is probably because the millennials have higher technological skill, considering the generation $\mathrm{Z}$ is a generation that has been exposed to digital technology from birth (digital native), so does the generation $\mathrm{Y}$ that is growing up with digital technology. These technological skills then lead to different patterns of information seeking for each generation, where generation $\mathrm{Y}$ and $\mathrm{Z}$ prefer digital content (in this case UGC) to find information about the lipstick that they want.

Table 3. Sample Demography by Occupation

\begin{tabular}{ll}
\hline Occupation & Number \\
\hline Student & 17 \\
Housewife & 10 \\
Employee & 39 \\
Entrepreneur & 9 \\
Civil servant & 8 \\
Professional & 24 \\
Others & 14 \\
\hline
\end{tabular}

Based on occupation, it can be seen from Table 3 that the most respondents work as employees that is as much as $32.23 \%$ of total respondent. The next most is of professionals and then the students. We can argue that this is because employees, professionals and students need more attractive appearance compared to housewives, entrepreneurs, civil servants and others.

Table 4. Sample Demography by Income

\begin{tabular}{ll}
\hline $\begin{array}{l}\text { Income (million rupiahs per month in } \\
\text { average) }\end{array}$ & Number \\
\hline$<5$ & 88 \\
$5-10$ & 26 \\
$10-15$ & 3 \\
$15-20$ & 3 \\
$>20$ & 1 \\
\hline
\end{tabular}

Respondents were also observed based on their income, in this case, average income per month. We categorized the income by interval of 5 million rupiah because generally those interval has quite a noticeable 
difference, from the lifestyle, cars, house, and so on. Based on Table 4, it can be seen that the most respondents have income below 5 million rupiah. The second largest is the range of income between 5 to 10 million rupiah. If those two are added together, a total of $114(94.21 \%)$ is obtained. This means that most respondents are in the middle to lower social class. Even so, it can be seen that although respondents are not of high social class, the need for lipstick as a support for appearance or included in lifestyle is also needed. Another thing that can be seen is that the utilization of UGC is not only for higher social class, but in the lower too. This can be a further discussion regarding content marketing and its relationship with social class.

Table 5. Sample Demography by Brand of UGC

\begin{tabular}{ll}
\hline Brand of UGC & Number \\
\hline Wardah & 59 \\
Revlon & 4 \\
Maybelline & 29 \\
Pixy & 9 \\
Viva & 5 \\
Others & 15 \\
\hline
\end{tabular}

In this study, we use five lipstick brands that achieve Indonesia's Top Brand in 2019. The five brands and the brand index are: Wardah (33.2\%), Revlon (9.2\%), Maybelline (7.7\%), Pixy (6.0\%) and Viva (4.5\%) (Frontier Groups, 2019). However, in this study we still offer "Other" option in order to see if there is a UGC that is not related to the five Top Brand lipsticks, or in other words, are there consumers from other brands that create or produce content. From Table 5, it can be seen that the most watched UGC is Wardah, with 59 respondents or $48.76 \%$ of the total respondents. This is relevant with the highest brand index. The second largest seen is Maybelline with 29 respondents or $23.97 \%$ of all respondents. This is different with the brand index achievement, where the second highest index brand is Revlon. Then the third largest is from the other brands as many as 15 people or $12.40 \%$ of all respondents. This is also interesting, considering the respondents in this study watched not only UGC about big brands, but also from brands that were not listed in Top Brand. This can be a subject for further discussion and research.

The description or description of the variables in this study uses the mean and standard deviation based on the division of categories from Simamora (2004). The results of data acquisition for each variable are summarized in the following table.

Table 6. Variable Means

\begin{tabular}{lll}
\hline Brand of UGC & Number & Category \\
\hline Co-creation & 5,195 & High \\
Empowerment & 4,849 & High \\
Community & 4,579 & High \\
Self-Concept & 4,783 & High \\
Involvement & 5,421 & Very high \\
CBBE & 5,458 & Very high \\
\hline
\end{tabular}

SmartPLS analyzes the relationship between variables and indicators, namely measurement/outer model and structural/inner model. Measurement model is a characteristic specification that explains the relationship between latent variables and their indicators. While the structural/inner model is a characteristic specification that explains the relationship between latent variables. The first step is to do outer model testing that resulted as follow. 


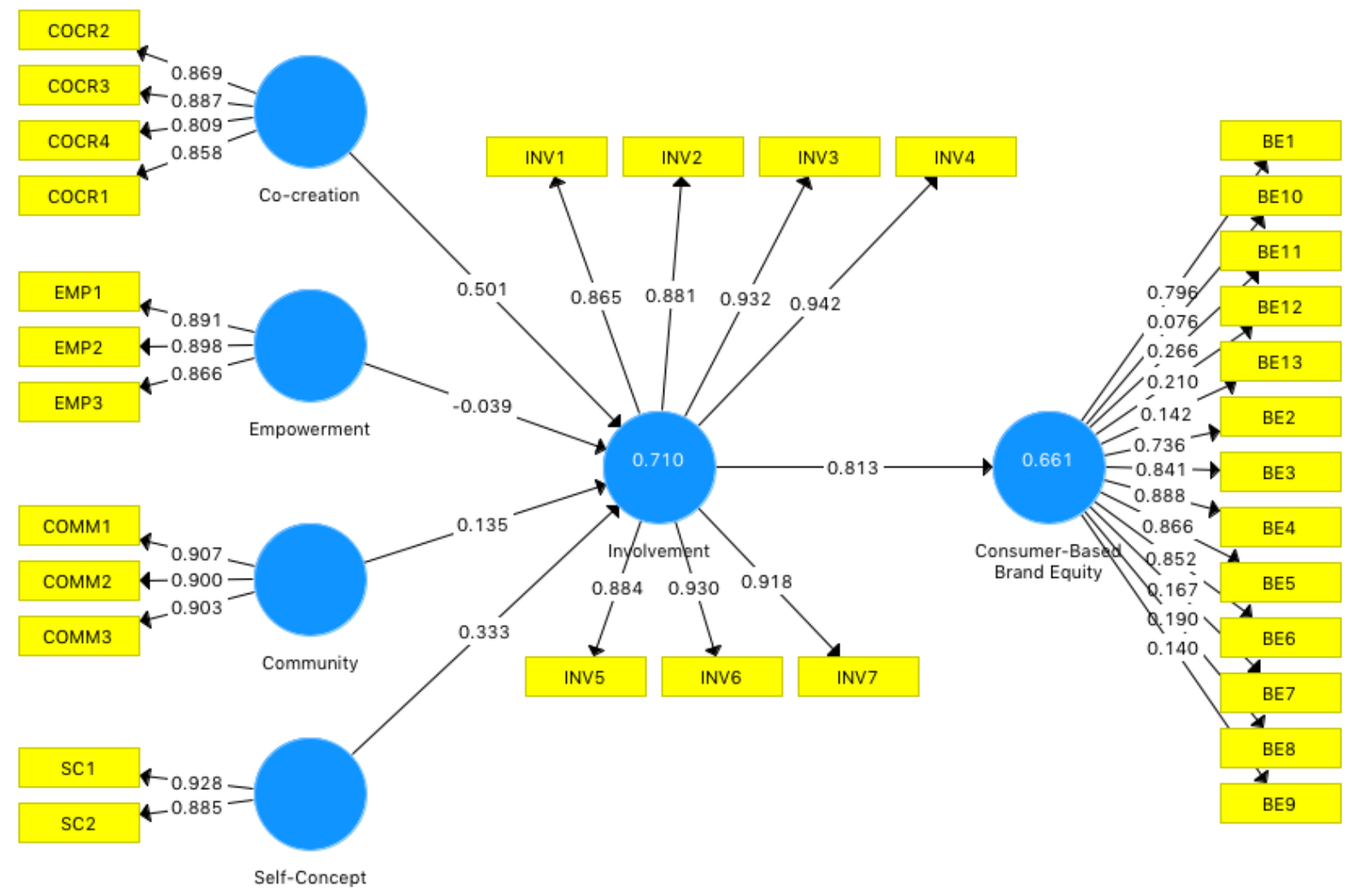

Fig. 2 Outer Model Test Result

Convergent validity is assessed based on outer loading. The criteria used for convergent validity is outer loading> 0.5. It can be seen from Figure 2 that there are 7 indicators that do not meet the convergent validity criteria, namely BE7, BE8, BE9, BE10, BE11, BE12, and BE13, so this indicator is not included in the next analysis. Then the outer loading was re-tested and found that all indicators met the convergent validity criteria.

Discriminant validity test is assessed based on cross loading measurements with the construct. Another method used to assess discriminant validity is to compare AVE roots for each construct with the correlation of all constructs in the model. The model has sufficient discriminant validity if the root of AVE for each construct is greater than the correlation of all constructs in the model, and the biggest cross loading is in the construct that it formed.

Table 7. Cross Loading Factor

\begin{tabular}{lllllll}
\hline \multirow{2}{*}{ Indicator item } & \multicolumn{7}{c}{ Construct } \\
\cline { 2 - 7 } & Co-creation & Empowerment & Community & Self-Concept & Involvement & CBBE \\
\hline COCR1 & 0.858 & 0.553 & 0.432 & 0.595 & 0.733 & 0.719 \\
COCR2 & 0.869 & 0.664 & 0.587 & 0.645 & 0.658 & 0.680 \\
COCR3 & 0.887 & 0.641 & 0.545 & 0.575 & 0.671 & 0.669 \\
COCR4 & 0.809 & 0.676 & 0.566 & 0.629 & 0.648 & 0.642 \\
EMP1 & 0.770 & 0.891 & 0.621 & 0.671 & 0.651 & 0.640 \\
EMP2 & 0.606 & 0.898 & 0.761 & 0.729 & 0.634 & 0.534 \\
EMP3 & 0.567 & 0.866 & 0.744 & 0.608 & 0.537 & 0.600 \\
COMM1 & 0.605 & 0.808 & 0.907 & 0.665 & 0.629 & 0.560
\end{tabular}




\begin{tabular}{lllllll} 
COMM2 & 0.473 & 0.678 & 0.900 & 0.626 & 0.514 & 0.463 \\
COMM3 & 0.583 & 0.664 & 0.903 & 0.653 & 0.613 & 0.591 \\
SC1 & 0.700 & 0.699 & 0.646 & 0.928 & 0.755 & 0.715 \\
SC2 & 0.583 & 0.678 & 0.663 & 0.885 & 0.605 & 0.581 \\
INV1 & 0.717 & 0.679 & 0.621 & 0.669 & 0.865 & 0.677 \\
INV2 & 0.690 & 0.566 & 0.523 & 0.662 & 0.882 & 0.815 \\
INV3 & 0.758 & 0.637 & 0.610 & 0.736 & 0.933 & 0.774 \\
INV4 & 0.793 & 0.629 & 0.586 & 0.682 & 0.942 & 0.766 \\
INV5 & 0.662 & 0.641 & 0.635 & 0.713 & 0.884 & 0.672 \\
INV6 & 0.711 & 0.596 & 0.582 & 0.676 & 0.930 & 0.733 \\
INV7 & 0.700 & 0.645 & 0.598 & 0.677 & 0.918 & 0.740 \\
BE1 & 0.685 & 0.709 & 0.672 & 0.688 & 0.723 & 0.782 \\
BE2 & 0.573 & 0.465 & 0.404 & 0.558 & 0.535 & 0.751 \\
BE3 & 0.629 & 0.508 & 0.450 & 0.503 & 0.603 & 0.848 \\
BE4 & 0.761 & 0.715 & 0.643 & 0.725 & 0.787 & 0.888 \\
BE5 & 0.620 & 0.421 & 0.385 & 0.524 & 0.679 & 0.877 \\
BE6 & 0.680 & 0.485 & 0.412 & 0.585 & 0.717 & 0.863 \\
\hline
\end{tabular}

Table 8. Correlation and Root of AVE

\begin{tabular}{lclllllll}
\hline Variable & AVE & $\begin{array}{l}\text { Root } \\
\text { of } \\
\text { AVE }\end{array}$ & $\begin{array}{l}\text { Co- } \\
\text { creation }\end{array}$ & Empowerment & Community & $\begin{array}{l}\text { Self- } \\
\text { Concept }\end{array}$ & Involvement & CBBE \\
\hline Co-creation & 0.733 & 0.856 & 0.856 & & & & & \\
Empowerment & 0.816 & 0.903 & 0.618 & 0.903 & & & & \\
Community & 0.700 & 0.837 & 0.793 & 0.600 & 0.836 & & & \\
Self-Concept & 0.783 & 0.885 & 0.737 & 0.797 & 0.668 & 0.885 & & \\
Involvement & 0.825 & 0.908 & 0.793 & 0.653 & 0.816 & 0.690 & 0.908 & \\
CBBE & 0.822 & 0.907 & 0.713 & 0.719 & 0.721 & 0.759 & 0.757 & 0.907 \\
\hline
\end{tabular}

Based on Table 7 it can be seen that the largest cross loading is in the construct that it forms, so it can be concluded that the research indicators meet discriminant validity. Whereas based on Table 8 , it can be seen that the root of AVE for each construct is greater than the correlation of all construct in the model so that it is declared valid in discriminant validity testing. In addition to the validity test, PLS also conducts a reliability test to measure the internal consistency of the measuring instrument. Reliability testing in PLS using composite reliability. 
Table 9. Composite reliability

\begin{tabular}{llll}
\hline Construct & Composite reliability's score & Rule of thumb & Status \\
\hline Co-creation & 0.917 & 0.7 & Reliable \\
Empowerment & 0.916 & 0.7 & Reliable \\
Community & 0.930 & 0.7 & Reliable \\
Self-Concept & 0.902 & 0.7 & Reliable \\
Involvement & 0.970 & 0.7 & Reliable \\
CBBE & 0.933 & 0.7 & Reliable \\
\hline
\end{tabular}

Based on Table 9, it can be seen that the composite reliability value of all variables is greater than 0.7 , so the entire construct is declared reliable. After passing the outer model testing stage, the next stage is the analysis of structural or inner models. Assessing based on the value of R-square is used to measure the level of variation in the changes of the independent variable to the dependent variable. The higher R-square means the better the prediction model of the research proposed.

Table 10. R-square

\begin{tabular}{ll}
\hline Endogenous Construct & R-square \\
\hline Involvement & 0.710 \\
CBBE & 0.661 \\
\hline
\end{tabular}

From Table 10, it can be seen that the R-square for the Involvement is 0.710 , meaning that Co-creation, Empowerment, Community, and Self-Concept able to explain $71.0 \%$ of Involvement, while $29.0 \%$ is explained by other variables outside this study. R-square of Involvement (0.710) is in the substantial category. R-square for the CBBE is 0.661, meaning that Involvement, Co-creation, Empowerment, Community, and Self-Concept able to explain $\mathrm{CBBE}$ by $66.1 \%$, while $33.9 \%$ is explained by other variables outside this study. R-square of CBBE $(0.661)$ is in the moderate category.

Inter-construct causality test in PLS structural model is assessed by the path coefficient or t-values for each path to test the significance. The path coefficient or inner model score indicated by the $\mathrm{t}$ statistic, must be greater than 1.98 for one-tailed testing at alpha $(\alpha) 5$ percent.

Table 11. Hypotheses test

\begin{tabular}{lllll}
\hline Hypotheses & Path & Path coefficient & t-statistic & Decision \\
\hline $\mathrm{H}_{1}$ & Co-creation $\rightarrow$ Involvement & 0,501 & 6,267 & Accepted \\
$\mathrm{H}_{2}$ & Empowerment $\rightarrow$ Involvement & $-0,039$ & 0,329 & Rejected \\
$\mathrm{H}_{3}$ & Community $\rightarrow$ Involvement & 0,135 & 1,612 & Rejected \\
$\mathrm{H}_{4}$ & Self-Concept $\rightarrow$ Involvement & 0,333 & 3,195 & Accepted \\
$\mathrm{H}_{5}$ & Involvement $\rightarrow$ Consumer-Based Brand Equity & 0,813 & 26,050 & Accepted \\
\hline
\end{tabular}

Of the five hypotheses proposed, there are two hypotheses rejected, that are $\mathrm{H}_{2}$ and $\mathrm{H}_{3} . \mathrm{H}_{2}$ (positive effect of empowerment on involvement) is rejected because the path coefficient is negative and the t statistic is less than 1.98. Whereas $\mathrm{H}_{3}$ (positive effect of community on involvement) was rejected because the $\mathrm{t}$ statistic was less than 1.98. In contrast, $\mathrm{H}_{1}, \mathrm{H}_{4}$, and $\mathrm{H}_{5}$ are accepted because they have positive path coefficients and the $\mathrm{t}$ statistic is greater than 1.98. Summary of the results of testing the research hypotheses is as follows:

1) $\mathrm{H}_{1}$ is accepted; it means that co-creation has positive effect on consumer involvement with the brand through UGC. The more consumer perceives that a brand is co-created, the higher their involvement. 
2) $\mathrm{H}_{2}$ is rejected; it means that consumer empowerment does not has positive effect on consumer involvement with the brand through UGC. The more consumer perceives that a brand can empower them, it does not necessarily increase their involvement with the brand through UGC.

3) $\mathrm{H}_{3}$ is rejected; it means that community does not has positive effect on consumer involvement with the brand through UGC. The more consumer perceives that a brand facilitates community, it does not necessarily increase their involvement with the brand through UGC.

4) $\mathrm{H}_{4}$ is accepted; it means that self-concept has positive effect on consumer involvement with the brand through UGC. The more consumer perceives that a brand expresses their self-concept, the higher their involvement with the brand through UGC.

5) $\mathrm{H}_{5}$ is accepted; it means that consumer involvement has positive effect on consumer-based brand equity. The higher the level of consumer involvement with UGC, the higher the consumer perceived brand equity.

This finding might be a consideration for the five Top Brand lipstick to pay more attention in the implementation of content marketing strategies through UGC to increase their perceived brand equity in the eyes of consumer. Another thing in the content marketing implementation are related to the company's openness in accepting input from consumers so that it allow the innovation from co-creation. Also there is need to encourage consumers to create content that is appropriate or truly expresses themselves completely.

Two of the four exogenous variables have been proved to have a significant positive effect on endogenous variables. While endogenous variables are also proved to have a positive and significant effect on other endogenous variables.

Table 12. Rank of influence by magnitude

\begin{tabular}{lll}
\hline Rank & Path & Path coefficient \\
\hline 1 & Involvement $\rightarrow$ Consumer-Based Brand Equity & 0.813 \\
2 & Co-creation $\rightarrow$ Involvement & 0.501 \\
3 & Self-Concept $\rightarrow$ Involvement & 0.333 \\
\hline
\end{tabular}

The path coefficient numbers in these variables have the following meanings:

1) Involvement $\rightarrow$ Consumer-Based Brand Equity $=0.813$, meaning that the influence of involvement on consumer-based brand equity of Top Brand lipstick consumers in Indonesia is 0.813 . This means that the higher customer involved with the product through UGC, the higher their brand equity. It means that the customer perceive that the product is more valuable, has higher quality, they become more aware and associated their self with the product more. The effect of customer involvement to CBBE is substantial, means that the management need to generates more UGC to increase the involvement level of their customer so the brand would be more "valuable" in the eye of the customer and get more loyal customer.

2) Co-creation $\rightarrow$ Involvement $=0.501$, meaning that the influence of co-creation on involvement of Top Brand lipstick consumers in Indonesia is 0.501. This means that the more customer perceived that the brand is co-created through UGC, the higher their involvement with the product. The effect of co-creation to involvement is moderate. Management need to selectively response their customer inputs from UGC and applied those inputs to the brand.

3) Self-Concept $\rightarrow$ Involvement $=0.333$, meaning that the influence of self-concept on involvement of Top Brand lipstick consumers in Indonesia is 0.333 . This means that the more customer perceives that the brand expresses their self-concept, the higher their involvement with the product through UGC. This effect is considered as weak, means that management should not concern a lot with how their brand talk about their customer's self-concept in UGC, just keep an adequate level of self-concept; more general, not too personal. This is probably because most customer is more influenced rather than influencing, so the self-concept is something dynamic, influenced with other self-concept, mainly of influencer. 


\section{CONCLUSIONS AND SUGGESTION}

This study aims to understand the relationship of UGC to Customer-Based Brand Equity, in the eye of the viewer, as it has bigger number than the creator. We tested a model from previous research but with different side of view. From this study, we find that UGC dimensions has effect on CBBE mediated by involvement level of customer. From the study of consumer of Indonesia Top Brand lipstick we able to draw some conclusions. First, the dimension of UGC that has significant influence on involvement are co-creation and self-concept. Second, the influence of co-creation on involvement is positive and considered as moderate with magnitude of 0.50 . Third, the influence of self-concept on involvement is positive and considered as weak with magnitude of 0.333 . Fourth, involvement has significant and positive effect on CBBE with magnitude of 0.813 which considered as substantial. Fifth, the contribution of UGC dimensions in explaining involvement is considered as substantial with R-square of 0.701. Sixth, the UGC dimensions and involvement altogether has moderate contribution in explaining CBBE with R-square of 0.661 .

This study has some limitations and need further research. First, we only tested the same model that has been proposed earlier from previous research, this model could be developed more with some motivational factors of viewer to watch UGC. Second, we only test the model in a narrow scope, that is consumer of product of lipstick. Future research could expand the scope to other industry to get more understanding, considering that nowadays many different industries, from cosmetics to smartphone, has content created by their customer. Third, we're not test the loop path as proposed from the previous research of Christodoulides et al. (2012), future research could take this path into consideration. Fourth, we suggest that it might be necessary to examine the effect of age and social class on UGC and also the effect of its moderation on the model of this study. Finally, our research shows that consumer empowerment and community does not significantly influence consumer online involvement with UGC. This is quite interesting because in online world is related closely with high social interactions and able to form a particular community based on their interests. However, it was found that the community apparently had no significant effect on online consumer online involvement. Therefore, it needs to further investigated to confirm this effect.

\section{REFERENCES}

Aaker, J. L. (1997). Dimensions of Brand Personality. Journal of Marketing Research, 34(3), 347-356.

Berthon, P., Pitt, L., \& Campbell, C. (2008). Ad Lib: When Customers Create the Ad. California Management Review, 50(4), 6-30.

Bloch, P. H., \& Richins, M. L. (1983). A Theoretical Model for the Study of Product Importance Perceptions. Journal of Marketing, 47(3), 69.

Bruns, A. (2007). Produsage: Towards a Broader Framework for User-Led Content Creation. Knowledge Management, 6(8), 99-106.

Burmann, C., and Arnhold U. (2008). User Generated Branding: State of the Art Research. Berlin: LIT Verlag Berlin-Hamburg-Münster.

Chaffey, D., Mayer, R., Johnston, K., \& Ellis-Chadwick, F. (2000). Internet marketing. Edinburgh: Pearson Education.

Christodoulides, G., Jevons, C., \& Bonhomme, J. (2012). Memo to marketers: Quantitative evidence for change - how user-generated content really affects brands. Journal of Advertising Research, 52(1), 53-64.

Christodoulides, G. (2009). Branding in the post-internet era. Marketing Theory, 9(1), 141-144.

Clarke, K., \& Belk, R. W. (1979). "The Effects of Product Involvement and Task Definition on Anticipated Consumer Effort" in NA - Advances in Consumer Research Volume 06, eds. William L. Wilkie, Ann Abor, MI : Association for Consumer Research, Pages: 313-3

Cobb-Walgren, C. J., Ruble, C. A., \& Donthu, N. (1995). Brand equity, brand preference, and purchase intent. Journal of Advertising, 24(3), 25-40.

Daugherty, T., Eastin, M. S., \& Bright, L. (2008). Exploring Consumer Motivations for Creating User-Generated Content. Journal of Interactive Advertising 8(2), 16-25.

Elisa, R., \& Gordini, N. (2014). Content Marketing Metrics: Theoretical Aspects and Empirical Evidence. European Scientific Journal, 10(34), 1857-7881.

Forrest, P. (2019). Content Marketing Today.

Forrest, P. and Piper, W. S. (2018.) Increasing Business Dependence on Social Media, presented at Society for Business, Industry and Economics Conference, Destin, April 10—13, 2018: FL Gensler. 
Gardner, B., and Levy, S. (1955). The Product and the Brand. Harvard Business Review, 33(2), 33-39.

Gunelius, S. (2011) Content Marketing for Dummies. New York: Wiley.

Halvorson, K. (2010). Content strategy for the web. Barkeley: New Riders.

Handley, A., \& Chapman. (2010). C.C. Content Rules. New York: Wiley

Harrison, T., Hunter, G. L., \& Waite, K. (2006). The Internet, Information and Empowerment. European Journal of Marketing, 40(9), 972-993.

Humphreys, A., \& Grayson, K. (2008). The Intersecting Roles of Consumer and Producer: A Critical Per- spective on Co-Production, Co-Creation and Prosumption. Sociology Compass, 2(3), 963-980.

Hupfer, N. T., \& Gardner, D. M. (1971). Differential involvement in Products and Issues: An Exploratory Study. Advances in Consumer Research, 2, 262-270.

Jefferson, S., \& Tanton, S. (2013). Valuable Content Marketing. How to make quality content the key of your business success. London: Kogan Page.

Jones, T. O., \& Sasser, W. E. Jr. (1995). Why satisfied customers defect. Harvard Business Review, 73(4), 88-99.

Keller, K.L. (1993). Conceptualizing, measuring and managing customer-based brand equity. Journal of Marketing, 57(1), 1-22

Keyes, J. (2006). Knowledge management, business intelligence and content management. Broken South Parken: Auerbach Publication

Knox, S., \& Walker, D. (2003). Empirical developments in the measurement of involvement, brand loyalty and their relationship in grocery markets. Journal of Strategic Marketing, 11, 271-286.

Kotler, P., Kertajaya, H., \& Setiawan, I. (2017). Marketing 4.0: Moving From Traditional to Digital. New Jersey: Wiley

Kotler, P., \& Keller, K. L. (2009). Manajemen Pemasaran (Jilid 13 Buku 2). Jakarta: Erlangga.

Krishnamurthy, S., \& Dou, W. (2008). Advertising with User-Generated Content: A Framework and Research Agenda. Journal of Interactive Advertising, 8(2), 1-4.

Krugman, H. (1965). The Impact of Television Advertising: Learning without Involvement. Public Opinion Quarterly, 29, 349-56.

Lieb, R. (2011). Content Marketing: think like a publisher. How to use content to market online and in social media. Indianapolis: Que Publishing

Nelli, R.P. (2012). Branded Content Marketing. Vita e. Milan: Pensier.

OECD. (2007). Participative Web and User-Created Content: Web 2.0, Wikis, and Social Networking. Paris: Organisation for Economic Co-operation and Development

Pires, G. D., Rita, P., \& Stanton J. (2006). The Internet, Consumer, Empowerment and Marketing Strategies. European Journal of Marketing, 40(9), 936-949.

Pulizzi, J. \& Barrett, N. (2009). Get content. Get customers. New York: McGraw Hill.

Rahimia, F. \& Hassanzadeh, J. (2013). The impact of website content dimension and e-trust on e-marketing effectiveness: the case of Iranian commercial saffron corporations. Information and Management, 50, 240247.

Ruffolo, B. (2017). What is Content Marketing? https;//www.impactbnd.com/blog/what-is-content-marketing

Saunder, M., Lewis, P., \& Thornhill, A. (2009). Research Methods for Business Students (5th Editon). Essex: Prentice Education Limited

Sekaran, U. \& Bougie. (2010). Research Methods for Business A Skill Building Approach. Sussex: Wiley

Sekaran, U. (2006). Metodologi Penelitian Untuk Bisnis (Edisi 4 Buku 2). Jakarta: Salemba Empat.

Sinha, A., \& Pappu, R. (1998). "Parcelling of the sub components of consumer-based brand equity using factorial survey: an empirical investigation in the New Zealand consumer electronics sector", Proceedings, Australia New Zealand Marketing Academy Conference (ANZMAC), University of Otago, Dunedin, December, pp. 2433-8.

Slater, D. (2014) Content marketing: recycling and reuse. New York: Media Corporation.

Vargo, S. L., \& Lusch, R. F. (2004). Evolving to A New Dominant Logic for Marketing. Journal of Marketing 68(1), 1-17

Washburn, J. H. \& Plank, R. E. (2002). Measuring brand equity: an evaluation of a consumer-based brand equity scale. Journal of Marketing Theory and Practice, 10(1), 46-62

Wathieu, L., Brenner, L., \& Carmon, Z. (2002). Consumer Control and Empowerment: A Primer. Marketing Letters, 13(3), 297-305

Yoo, B. \& Donthu, N. (2001). Developing and validating a multidimensional consumer-based brand equity scale. Journal of Business Research, 52, 1-14 
Yoo, B. and Donthu, N. (2002). Testing cross-cultural invariance of the brand equity creation process. Journal of Product \& Brand Management, 11(6), 380-98

Yoo, B., Donthu, N., \& Lee, S. (2000). An examination of selected marketing mix elements and brand equity. Journal of the Academy of Marketing Science, 28(2), 195-211

Zaichkowsky, J. L. (1985). Measuring the Involvement Construct. Journal of Consumer Research, 12(3), 341352

Zaichkowsky, J. L. (1994). The Personal Involvement Inventory: Reduction, Revision, and Application to Advertising. Journal of Advertising, 23(4), 59-70 